$\mathrm{Nr} 4(61), 2019$, s. 379-405

https://doi.org/10.12797/Politeja.16.2019.61.21

\author{
Marcin WAEDOCH (D) \\ Uniwersytet Kazimierza Wielkiego w Bydgoszczy \\ waldoch@ukw.edu.pl
}

\title{
DOCIEKLIWI JAKO NOWY RUCH SPOŁECZNY: ASPEKTY POLITYCZNE REALIZACJI PRAWA DOSTĘPU DO INFORMACJI PUBLICZNEJ W POLSCE ${ }^{1}$
}

ABSTRACT The Inquisitives as a New Social Movement: Political Aspects of Exercising the Right for the Access to Information in Poland

In this paper, the author analyzes the new social movement labeled „The Inquisitives”. It apparently has its roots in political thought and in philosophy of „the right to know”. Poland adopted the Act on Access to Public Information (2001) to give citizens the formal right to inquire about the public affairs. The information society strives for information about political issues, and about political-public affairs. The author of this paper has stated two hypothesis that (1) a new social movement - the Inquisitives has been occurring in Poland and (2) access to public information has been used for political struggle. The author aims to explore aims, genesis, background, roles, functions, and political values of The Inquisitives within categories such as political scandals, corruption, interest groups, power concentration.

Keywords: political struggle, counter-power, Inqusitives, civil society, public information

Słowa kluczowe: walka polityczna, przeciwwładza, dociekliwi, społeczeństwo obywatelskie, informacja publiczna

\footnotetext{
Artykuł powstał w ramach działania badawczego finansowanego przez Narodowe Centrum Nauki nr 2017/01/X/HS5/01998, pod tytułem: Dociekliwi jako nowy ruch spoteczny: analiza porównawcza aspektów politycznych realizacji prawa dostępu do informacji publicznej w Nowej Zelandii i Polsce.
} 


\section{WSTĘP}

Informacje i sposoby jej badania oraz pozyskiwania zostały uznane za jedną z najważniejszych przestrzeni podlegających silnym przekształceniom $w$ wyniku przemian technologicznych ${ }^{2}$. Wiedza, wywiedziona przecież z informacji, staje się obecnie towarem na sprzedaż. Ponadto przypisuje się jej siłę wytwórczą. Wiedza jest też koniecznym czynnikiem w procesie zdobywania władzy. Obecną walkę o informację, nawet na poziomie stosunków międzynarodowych, porównuje się z dawnymi walkami o surowce i terytoria ${ }^{3}$. Jak pisał Jean-François Lyotard:

Merkantylizacja wiedzy nie będzie bowiem mogta pozostawić nietkniętym przywileju, który nowoczesne panstwa zachowywaty i zachowuja nadal $w$ dziedzinie wytwarzania i rozpowszechniania informacji. Idea, że informacja należy do tego "mózgu” czy tego „ducha" spoteczeństwa, którym jest państwo, ulegnie przedawnieniu w miarę, jak wzmacniać się będzie zasada przeciwna, zgodnie z która spoteczeństwo istnieje i rozwija się tylko wte$d y$, gdy krażace wnim komunikaty sa bogate winformacje i tatwe do rozszyfrowania. Państwo zacznie jawić się jako czynnik zaciemnienia $i$ „szumu” dla ideologii „przejrzystości” komunikacyjnej, która idzie w parze z komercjalizacja wiedzy. Istnieje ryzyko, że pod tym wtaśnie kątem z nowa ostrościa stanie problem stosunków między instancjami ekonomicznymi i państwowymi. Już w poprzednich dekadach te pierwsze mogty zagrozić stabilności tych drugich dzięki nowym formom cyrkulacji kapitatów, którym nadano ogólne miano przedsiębiorstw wielonarodowych ${ }^{4}$.

W tej perspektywie już według Lyotarda państwo stawało wobec konieczności rewizji swych relacji zarówno z sektorem prywatnym, jak i ze społeczeństwem obywatelskim 5 . Informacje w rozwiniętym społeczeństwie informacyjnym stają się niezbędne, nie tylko dla podtrzymania systemu i jego funkcji, lecz także przez wzgląd na konieczność optymalizacji jego działania, stąd też dostęp do informacji publicznej autor traktuje zarówno jako proces umożliwiający utrzymanie systemu i jego legitymizację, jak i proces optymalizacji działania systemów politycznych ${ }^{6}$. W tym drugim przypadku można rozważać informacje publiczne jako, analogicznie, kapitał inwestycyjny w gospodarce. Dostęp do informacji publicznej i powstające wokół tej praktyki zjawiska polityczne należy postrzegać również przez pryzmat koncepcji Ulricha Becka, czyli przeciwwtadzy, która upodmiotowiła globalne społeczeństwo obywatelskie w stosunku do władzy politycznej, koncentrującej się nie jedynie w państwach narodowych, ale w warunkach globalizacji również w rękach dysponentów wielkiego kapitału, czyli w korporacjach transnarodowych ${ }^{7}$.

2 J.-F. Lyotard, Kondycja ponowoczesna. Raport o stanie wiedzy, przeł. M. Kowalska, J. Migasiński, Warszawa 1997, s. 27.

Tamże, s. 30-32.

Tamże, s. 32-33.

Tamże.

Zob. tamże, s. 33-34.

U. Beck, Wtadza i przeciwwtadza w epoce globalnej, przeł. J. Łoziński, Warszawa 2005, w wielu miejscach. 
Wielka waga dostępu do informacji publicznej spowodowała wyłonienie się nowego ruchu społecznego, który autor nazwał ruchem dociekliwych - ruchu nieformalnego, działającego na skalę globalną, bowiem prawo dostępu do informacji publicznej obowiązuje obecnie w ok. 90 państwach świata. Podbudowę filozoficzną, ideową dla realizacji dostępu do informacji publicznej widzi się w myśli: Immanuela Kanta, postulującego zasadę jawności publicznej; Jürgena Habermasa, który dostrzegał proces integracji sfery publicznej pod patronatem instytucji państwa i stowarzyszeń; Karla Poppera, który przecież postulował model społeczeństwa otwartego; Maxa Horkheimera i jego postulatu prawa obywateli po prostu do tego, żeby wiedzieć, stanowiącego też wyrazem chęci emancypacji i realizacji postulatu rozumnego społeczeństwa. Nadto realizacja prawa dostępu do informacji publicznej jest wyrazem idei krytycznego rozumu, odwołując się do szkoły krytycznej związanej m.in. z Erichem Frommem i Herbertem Marcuse'em ${ }^{8}$. Zaś w perspektywie Amartyi Sena gwarancje jawności są właśnie wyrażane w ustawach o dostępie do informacji publicznej'. W jego ocenie gwarancje te stanowią zabezpieczenie przed [...] korupcja, nieodpowiedzialnościa finansowa i ukradkowymi machinacjami ${ }^{10}$.

Najwcześniej na świecie dostęp do dokumentów instytucji publicznych zagwarantowała Szwecja, zgodnie z ustawą o wolności prasy z 1766 r. ${ }^{11} \mathrm{~W}$ świecie Zachodu prawo dostępu do informacji publicznej jest kodyfikowane od lat 60. XX w. (USA) oraz w latach 80. XX w. (Nowa Zelandia), choć pierwszy akt związany z wprowadzeniem takiego ustawodawstwa przyjęto w Finlandii w 1951 r., zaś Wielka Brytania przyjęła je dopiero w 2000 r. $^{12}$ Jednak to rozwój nowych technologii komunikacyjnych dał asumpt do wytworzenia się nowego ruchu społecznego: dociekliwych. Jaki jest to ruch, autor próbował odpowiedzić, charakteryzując go w studium poświęconym działalności dociekliwych w Nowej Zelandii. Stąd należy przyjąć, że dociekliwi jako nowy ruch spoteczny to niesformalizowana grupa sktadająca się z osób fizycznych, korzystajacych z uniwersalnego prawa dostępu do informacji publicznej dla celów wtasnych bądź na skutek troski o stan spraw publicznych i chęci poprawy jakości życia, którzy przez swoje dziatanie wptywaja na sytuacjępolityczna $w$ danej wspólnocie politycznej. $\mathrm{Z}$ natury prawa dostępu do informacji publicznej wynika konstatacja, że dociekliwi charakteryzują się wysokim stanem świadomości politycznej. Co istotne dla rozumienia współcześnie realizacji prawa dostępu do informacji publicznej to fakt zapisania tego prawa w art. 19 Powszechnej

8 M. Wałdoch, Dociekliwi jako nowy ruch spoteczny: aspekty polityczne prawa dostępu do informacji publicznej w Nowej Zelandii, „Politeja” 2017, nr 3(48), s. 257-259, 272, https://doi.org/10.12797/ Politeja.14.2017.48.1.

9 A. Płachciak, Sena koncepcja rozwoju jako wolności a idea sustainable development, „Annales. Etyka w Życiu Gospodarczym” 2010, Vol. 13, nr 1, s. 149-156, [online] http://www.annalesonline.uni.lodz. pl/archiwum/2010/2010_01_plachciak_149_156.pdf, 12 IV 2018.

10 A. Sen, Rozwój i wolność, przeł. J. Łoziński, Poznań 2002, s. 54.

11 Zob. G. Rydlewski, P. Szusztakiewicz, K. Golat, Udzielanie informacji przez administracje publiczna (teoria i praktyka), Warszawa 2012, s. 43.

12 A. Demczuk, Dostęp do informacji publicznej w Polsce. Analiza krytyczna, „Teka Komitetu Politologii Stosunków Międzynarodowych” 2010, nr 5, s. 196-197. 
deklaracji praw człowieka ${ }^{13}$. Dynamika korzystania z prawa dostępu do informacji publicznej ma potencjał wzrostowy w związku ze skrajną indywidualizacją postaw obywateli ${ }^{14}$. Polska znajduje się więc w gronie ok. 90 państw świata gwarantujących obywatelom prawo dostępu do informacji publicznej. W Polsce podstawami tej gwarancji są: ustawa z 2001 r. o dostępie do informacji publicznej ${ }^{15}$, obowiązująca od 1 stycznia 2002 r.; ustawa z 2008 r. o udostępnianiu informacji o środowisku i jego ochronie, udziale społeczeństwa w ochronie środowiska oraz o ocenach oddziaływania na środowisko $^{16}$; art. 61 Konstytucji RP z 1997 r. (oraz art. 51, 54, 74) ${ }^{17}$; inne ustawy szczegółowe. Do czasu wejścia w życie ustawy o dostępie do informacji publicznej to art. 61 Konstytucji RP był podstawą do ubiegania się o dostęp do informacji publicznej ${ }^{18}$.

Zapewnienie dostępu do informacji publicznej w Polsce na podstawie ustawy szczegółowej stało się wyzwaniem dla elit politycznych, które w 1997 r. rozpoczęły starania o taki akt normatywny. W tej sprawie pierwszy projekt złożyli członkowie Unii Pracy, czyli partii socjalistycznej. Projekt ten nie miał dalszego biegu przez wzgląd na zakończenie II kadencji Sejmu RP. Do prób uchwalenia ustawy o dostępie do informacji publicznej powrócono w 2000 r., kiedy grupa posłów, reprezentowana przez posła Ryszarda Wawryniewicza z Akcji Wyborczej Solidarność, złożyła projekt ustawy. Ten właśnie projekt stał się podstawą obowiązującego obecnie aktu prawnego. Ówczesny rząd RP premiera Jerzego Buzka w pełni poparł starania o uchwalenie szczegółowej ustawy o dostępie do informacji publicznej. Ustawę o dostępie do informacji publicznej nowelizowano dotąd już kilkanaście razy, m.in. w kierunku umożliwienia dostępu do informacji publicznej „każdemu”, w tym bezpaństwowcom oraz obywatelom państw nieprzyjaznych lub wręcz wrogich. Ponadto informację publiczną udostępnia się osobom niepełnoletnim, które przekroczyły 13. rok życia ${ }^{19}$. Do kategorii „każdego" nie zalicza się osób ubezwłasnowolnionych, w Polsce pozbawionych prawa dostępu do informacji publicznej ${ }^{20}$. Nadto obowiązująca jest w tym zakresie Europejska konwencja praw człowieka, a szczególnie jej zapis w art. $10^{21}$. Na polskim gruncie praw-

13 M. Wałdoch, Dociekliwi jako nowy ruch spoteczny..., s. 257-259, 272.

14 M. Castells, Spoteczeństwo sieci, przeł. M. Marody i in., red. M. Marody, Warszawa 2011.

15 Ustawa z dnia 6 września 2001 r. o dostęie do informacji publicznej, Dz.U. 2001, nr 112, poz. 1198.

16 Ustawa $z$ z dnia 3 października 2008 r. o udostępnianiu informacji o środowisku i jego ochronie, udziale spoteczeństwa w ochronie środowiska oraz o ocenach oddziatywania na środowisko. Tekst jednolity, Dz.U. 2008, nr 199 poz. 1227.

17 Konstytucja Rzeczypospolitej Polskiej z dnia 2 kwietnia 1997 r. uchwalona przez Zgromadzenie Narodowe w dniu 2 kwietnia 1997 r., przyjęta przez Naród w referendum konstytucyjnym w dniu 25 maja 1997 r., podpisana przez Prezydenta Rzeczypospolitej Polskiej w dniu 16 lipca 1997 r., Dz.U. 1997, nr 78, poz. 483.

18 A. Demczuk, Dostęp do informacji publicznej w Polsce..., s. 203.

19 Choć oczywiste jest, że o dostęp do informacji publicznej walczyć będą przedstawiciele ruchów na rzecz praw dziecka, tak aby niepełnoletni mieli prawo do informacji publicznej bez względu na wiek.

20 M. Bidziński, M. Chmaj, P. Szustakiewicz, Ustawa o dostępie do informacji publicznej. Komentarz, Warszawa 2018.

21 Europejska konwencja praw cztowieka, [online] https://www.echr.coe.int/Documents/Convention POL.pdf, 10 VI 2018. 
nym przyjęło się, że [...] każda informacja o sprawach publicznych stanowi informacje publiczna $w$ rozumieniu ustawy $i$ podlega udostępnieniu i ponownemu wykorzystaniu [...] informacja publiczna obejmuje każda wiadomość wytworzonq czy posiadana przez szeroko rozumiane wtadze publiczne oraz osoby lub podmioty petniace funkcje publiczne $[\ldots]^{22}$. Efektem tak rozumianej informacji publicznej ma być spełnienie standardów $d e-$ mokratycznego państwa prawnego, co według prawników wyklucza działalność na rzecz spełniania potrzeb indywidualnych, komercyjnych lub stużacych celowej dezorganizacji państwa $a^{23}$. I jak się zauważa: informacja publiczna stanowi oręż $w$ walce $z$ przedstawicielami wtadzy, sasiadami czy nawet przemystowymi potentatami ${ }^{24}$. Instytucje w Polsce nie mogą żądać od obywateli np. wskazywania interesu prawnego, czyli nie można ubiegać się, aby obywatel składający zapytanie o informację publiczną uzasadniał ją w jakikolwiek sposób, jeśli udostępnienie informacji nie wiąże się z koniecznością tzw. przetworzenia informacji, czyli dodatkowego nakładu czasu i środków. Obywatele mogą natknąć się na barierę kosztową w procesie uzyskiwania dostępu do informacji publicznej - choć z zasady dostęp do niej jest bezpłatny, to jeśli wymaga on dodatkowego nakładu środków, na obywatela może zostać nałożona opłata. Wniosek o dostęp do informacji publicznej nie musi być też podpisany przez wnioskodawcę ${ }^{25}$, a w zasadzie obywatel ma prawo do anonimowości w tym procesie i nie musi nawet wykazywać swojego imienia i nazwiska. Nie jest nawet zobowiązany do sprawdzania faktu doręczenia e-maila z zapytaniem o informację publiczną ${ }^{26}$.

Liberalna konstrukcja polskiej ustawy o dostępie do informacji publicznej sprzyja, jak uważają prawnicy, nadużywaniu prawa ${ }^{27}$, choć w zamyśle twórców ustawy, co wykazali w uzasadnieniu do jej projektu, pisano, że [...] obywatele uzyskują realne możliwości wykorzystania i obrony swych konstytucyjnych praw wobec wtadzy publicznej $j^{28}$. Prawo dostępu do informacji publicznej jest gwarantowane nie tylko przez prawo krajowe, lecz także przez prawo międzynarodowe, w tym przez prawo unijne, i uznane jest za prawo fundamentalne. W dokumentach unijnych pisze się wręcz o prawowitości systemu prawnego dzięki gwarantowaniu obywatelom dostępu do informacji publicznej

22 M. Kowalski, Nadużycie prawa do informacji publicznej, „Zeszyty Naukowe Sądownictwa Administracyjnego" R. 12, 2016, nr 2(65), s. 51.

23 Tamże.

24 Z. Jóźwiak, Przetomowy wyrok w sprawie informacji publicznej. Za prace przy anonimizacji danych należy się zaptata, „Dziennik Gazeta Prawna” 2016, 9 IX, [online] http://prawo.gazetaprawna.pl/ artykuly/974540,informacja-publiczna-za-prace-przy-anonimizacji-danych-nalezy-sie-zaplata.html, 19 VI 2018.

25 M. Kowalski, Nadużycie prawa..., s. 52.

26 D. Frey, Nadawca maila nie musi sprawdzać doręczenia, „Rzeczpospolita” 2017, 28 IV, [online] http:// www.archiwum.rp.pl/artykul/1346258-Nadawca-maila-nie-musi-sprawdzac-doreczenia.html, 22 VI 2018.

27 M. Kowalski, Nadużcie prawa..., s. 53.

28 Projekt ustawy o dostępie do informacji publicznej, Sejm RP III kadencji, druk nr 2094, Warszawa, 30 VI 2000, [online] http://orka.sejm.gov.pl/Rejestrd.nsf/wgdruku/2094/\$file/2094.pdf, 18 VI 2018. 
i w rezultacie realizacji polityki przejrzystości, czyli jawności [...] sprawowania wtadzy w państwie demokratycznym ${ }^{29}$. Niestety w Polsce nie ma rzecznika dostępu do informacji publicznej, tym samym w sensie ustrojowym nie ma organu umocowanego do działań w tej sferze ${ }^{30}$ (jak przykładowo mamy do czynienia z Rzecznikiem Praw Dziecka). W pewnym zakresie takie obowiązki może wypełniać Rzecznik Praw Obywatelskich. Pisze się w tym względzie wręcz o informacji publicznej jako o narzędziu antykorupcyjnym w rękach społeczeństwa obywatelskiego ${ }^{31}$. Informacja odgrywa bardzo istotną rolę, a informacja publiczna jest elementem tej rzeczywistości. Strategicznym zasobem w społeczeństwie informacyjnym stał się kapitał intelektualny, a nie kapitał finanso$\mathrm{wy}^{32}$. Ponadto informacja jest podstawowym zasobem strategicznym, a wiedza i informacja przedmiotem kupna-sprzedaży ${ }^{33}$. Dlatego drugim obliczem dostępu do informacji jest jej poufność przez wzgląd na newralgiczne znaczenie informacji dla zagadnień bezpieczeństwa państwa. Stąd wprowadzono w życie ustawę z 2010 r. o ochronie informacji niejawnych ${ }^{34}$, wyznaczając w ten sposób w zasadzie granice jawności na gruncie prawnym, ukazując wyższość interesów publicznych nad prywatnymi ${ }^{35}$, choć odmowa dostępu do informacji niejawnych musi być uzasadniona ${ }^{36}$. Na bazie szerokiego dostępu do informacji może kształtować się społeczeństwo wiedzy (społeczeństwo informacyjne $)^{37}$, dlatego jasne jest, że budulcem takiego społeczeństwa będzie dostęp do informacji. Informacja jest obecnie podstawą wiedzy.

Internet, dzięki temu, że umożliwia funkcjonowanie sfery wyrażania własnych opinii w sposób nieskrępowany (Web 2.0), stał się narzędziem również do obchodzenia monopoli informacyjnych, w tym, jak się pisze, monopolu państwa. Nadto Internet jest obecnie kanałem komunikacji z administracją rządową, publiczną. Działania dokonywane w Internecie przez obywateli wzmocniły znacząco społeczeństwo obywatelskie. Z tego powodu uznaje się, że obecnie Internet i aktywność w nim oddziałują na procesy decyzyjne. Wykorzystuje się go do uzyskiwania informacji od instytucji publicznych. Dzięki tej rzeczywistości pojawiły się nowe narzędzia do kreowania polityki przez posługiwanie się informacjami uzyskanymi nawet drogą elektroniczną. Pisze się nawet, jak przedstawił Miron Lakomy, że realizacja prawa dostępu do informacji publicznej stanowiła podstawę aktywności politycznej w sferze obywatelskiej, ale drugą stroną tej

29 J. Taczkowska-Olszewska, Dostęp do informacji publicznej w polskim systemie prawnym, Warszawa 2014, s. VII, Monografie Prawnicze.

30 A. Demczuk, Dostęp do informacji publicznej..., s. 211.

31 Tamże, s. 203.

32 M. Lakomy, Cyberprzestrzeń jako nowy wymiar rywalizacji i wspótpracy państw, Katowice 2015, s. 43, Prace Naukowe Uniwersytetu Śląkiego w Katowicach, nr 3293.

33 Tamże, s. 55.

34 Ustawa z dnia 5 sierpnia 2010 r. o ochronie informacji niejawnych, Dz.U. 2010, nr 182, poz. 1228.

35 J. Taczkowska-Olszewska, Dostęp do informacji publicznej..., s. XII.

36 E. Świętochowska, Brak dostępu do informacji niejawnych trzeba uzasadnić, „Dziennik Gazeta Prawna" 2017, 20 VII, [online] http://prawo.gazetaprawna.pl/artykuly/1059037,brak-dostepu-doinformacji-niejawnych-uzasadnienie.html, 25 VI 2018.

37 Zob. M. Castells, Koniec tysiąclecia, przeł. J. Stawiński, S. Szymański, red. M. Marody, Warszawa 2009. 
rzeczywistości, w związku z dynamicznym rozwojem technologii, jest zwiększona możliwość wpływu aparatu państwowego na postawy obywateli. Informacja jest dobrem ekonomicznym i podstawowym zasobem ${ }^{38}$.

Jednocześnie za Alfredo M. Bonanno można wskazać, że obywatele będą się w przyszłości dzielić na włączonych w system polityczny i wyłączonych z niego dzięki dostępowi do informacji, w tym do informacji publicznej. Uprzywilejowanymi obywatelami będą ci posiadający dostęp do informacji i zdolni odciąć od tego dostępu pozostałą część obywateli ${ }^{39}$. W tym można dostrzegać słabość obecnie obowiązujących zapisów o dostępie do informacji publicznej, nie dają one bowiem obywatelom możliwości monitoringu działalność korporacji transnarodowych. Za niewielki wyłom w tym stanie rzeczy należy uznać publikowanie przez Ministerstwo Finansów danych z zeznań podatników podatku dochodowego od osób prawnych, których wartość przychodu uzyskana w roku podatkowym przekroczyła $50 \mathrm{mln}$ euro ${ }^{40}$. Uznać zaś należy, że kanał komunikacji jest znaczącym czynnikiem przyjmowania znojów życia codziennego. Przedsiębiorcy, którzy są w stanie racjonalnie wyjaśnić pracownikom przyczyny ich niskich zarobków, znajdują wśród nich zrozumienie i akceptację. Transparentność prowadzi m.in. do spłaszczenia płac - co można zaobserwować w Skandynawii - a w konsekwencji być może i do zmniejszania nierówności społecznych ${ }^{41}$.

W zakresie rozumienia tego, czym są nowe ruchy społeczne i jak je charakteryzować, autor czerpał ze wskazań Grażyny Ulickiej, według której nowe ruchy społeczne charakteryzują się powtarzalnością działań społeczno-politycznych, przeciwnie do incydentalnych zdarzeń i wypadków ${ }^{42}$, z myśli Clausa Offego, dla którego nowe ruchy społeczne nie posiadają formalnych liderów oraz powstają oddolnie, oraz z idei Alaina Touraine’a, według którego nowe ruchy społeczne koncentrują się przede wszystkim na walce w obronie praw człowieka. Nowe ruchy społeczne angażują się w proces zmiany politycznej i społecznej, wchodzą w konfliktowe działania zbiorowe, tworzą nieformalne sieci, cechują się świadomością zbiorową i świadomością wspólnego celu ${ }^{43}$.

38 M. Lakomy, Cyberprzestrzeń jako nowy wymiar rywalizacji..., s. 61-63.

39 Zob. P. Malendowicz, Ruchy spoteczne i myśl polityczna - co, jak i po co badać?, „Polityka i Społeczeństwo" 2016, nr 4(14), s. 16-17, https://doi.org/10.15584/polispol.2016.4.1.

40 Obowiązek publikacji, Ministerstwo Finansów, [online] https://www.mf.gov.pl/ministerstwo-finansow/dzialalnosc/indywidualne-dane-podatnikow-cit/-/asset_publisher/kYC4/content/obowiazek-publikacji-1 ?redirect=https\%3A\%2F\%2Fwww.mf.gov.pl\%2Fministerstwo-finansow\%2Fdzial alnosc\%2Findywidualne-dane-podatnikow-cit\%3Fp_p_id\%3D101_INSTANCE_kYC4\%26p_p_ lifecycle\%3D0\%26p_p_state\%3Dnormal\%26p_p_mode\%3Dview\%26p_p_col_id\%3D column-2\%26p_p_col_count\%3D1\#p_p_id_101_INSTANCE_kYC4_, 27 IV 2018; M. Szulc, Ł. Zalewski, Podatki największych przedsiębiorstw: więcej jawności niż $w$ Polsce tylko $w$ Skandynawii i Australii, „Dziennik Gazeta Prawna” 2017, 4 IV, [online] http://podatki.gazetaprawna.pl/artykuly/1032536,jawne-podatki-najwiekszych-przedsiebiorstw-ustawa-cit.html, 27 VI 2018.

41 Should You Pay Be Private?, BBC, The Real Story, 10 II 2018, [online] http://www.bbc.co.uk/programmes/w3csvqgm, 8 VI 2018.

42 G. Ulicka, Nowe ruchy spoteczne. Niepokoje i nadzieje wspótczesnych spoteczeństw, Warszawa 1993, s. 7.

43 D. della Porta, M. Diani, Ruchy spoteczne. Wprowadzenie, przeł. A. Sadza, Kraków 2009, s. 23-26, Politika. 
O polityczności badanego zjawiska świadczy jego charakter uwarunkowany rozumieniem tego dostępu jako realizacji praw obywatelskich, które to są z samej swej istoty immanentnie polityczne.

W zakresie zagadnienia podjętego przez autora nie ma w Polsce żadnych opracowań ani studiów cząstkowych, a przynajmniej autor takich studiów nie odnalazł, mimo przeprowadzenia dogłębnej i szerokiej kwerendy. O ile więc istnieją rozległe studia nad wykorzystaniem dostępu do informacji publicznej w Polsce z zakresu nauk prawnych ${ }^{44}$, a nawet $w$ relacji do wybranych aspektów prawnych dostępu do informacji publicznej w Europie ${ }^{45}$, o tyle nie ma w zakresie nauk o polityce prac, które ukazywałyby aspekty polityczne dostępu do informacji publicznej. Dużą część studiów nad dostępem do informacji publicznej poświęcono w Polsce temu zagadnieniu w rzeczywistości samorządowej, co świadczy o dostrzeganiu znaczenia wpływu polityki lokalnej na kształtowanie się ładu politycznego ${ }^{46}$. Część prac skupiono na zagadnieniach problemowych, takich jak dostęp do informacji publicznej a prawo do prywatności, ochrony działalności gospodarczej i zawodowej ${ }^{47} \mathrm{i}$ wymóg ochrony danych osobowych.

\section{HIPOTEZA, METODA I MATERIAŁ EMPIRYCZNY}

W niniejszym studium postawiono hipotezę, że wokół realizacji prawa dostępu do informacji publicznej ujawnił się w Polsce nowy ruch społeczny dociekliwych. Natomiast hipotezę pomocniczą stanowi przypuszczenie, że dostęp do informacji publicznej w Polsce jest wykorzystywany w walce politycznej. Dla rozwiązania tak zakreślonych hipotez autor postawił następujące pytania badawcze:

1. Jakie są źródła ideologiczne dociekliwych w Polsce?

2. W jakim stopniu dociekliwi działają grupowo? Jak często działają indywidualnie i w jakich przypadkach?

3. Jakie są motywy działalności politycznej dociekliwych w Polsce?

4. Jakie są główne żądania dociekliwych w Polsce?

5. W jakim stopniu ruch dociekliwych można wiązać z globalizacją protestu?

6. Jak działalność dociekliwych wpływa na polski system polityczny?

7. W jakiej mierze wykorzystuje się informację publiczną do manipulowania opinią publiczną?

44 Zob. Dostep do informacji publicznej, red. P. Szustakiewicz, Warszawa 2016; J. Taczkowska-Olszewska, Dostęp do informacji publicznej...

45 Zob. Dostęp do informacji publicznej w Polsce i w Europie. Wybrane zagadnienia prawne, red. E. Pierzchała, M. Woźniak, Opole 2010.

46 Zob. Dostęp do informacji publicznej w praktyce samorzadu terytorialnego. Konferencja, 19 czerwca 2015 r., red. S. Jakubczak, Warszawa 2015; Przyjazny urząd? Dostęp do informacji publicznej na wniosek w gminach i miastach województwa śląskiego. Raport z monitoringu, oprac. G. Wójkowski, J. Podgórska-Rykała, Katowice 2012.

47 R. Taradejna, M. Taradejna, Dostęp do informacji publicznej a prawna ochrona informacji dotyczacych dziatalności gospodarczej, spotecznej i zawodowej oraz życia prywatnego, Torun 2003. 
8. W czym przejawiają się znaki zagrożenia bezpieczeństwa państwa w związku $\mathrm{z}$ realizacją prawa dostępu do informacji publicznej?

9. Jak do prawa dostępu do informacji publicznej ustosunkowywali się rządzący w Polsce od czasu jej obowiązywania?

10. Jakie bariery i jakie możliwości wiążą obywateli z dostępem do informacji publicznej?

11. W jakiej mierze dostęp do informacji publicznej jest skutecznym narzędziem wpływu na sferę publiczną?

12. Jakie są wektory przemian wiązane z prawem dostępu do informacji w Polsce?

Źródła i materiał empiryczny stanowiły dokumenty orzecznictwa sądowego i dokumenty $\mathrm{z}$ archiwów dociekliwych $\mathrm{w}$ Polsce. Nadto autor korzystał z literatury przedmiotu oraz z analizy nowych mediów i mediów elektronicznych. Dodatkowo studium zostało uzupełnione wywiadami z dociekliwymi. Autor dokonał także obserwacji uczestniczącej, wykorzystując prawo dostępu do informacji naukowej w pracy naukowej i działalności społecznej. Oprócz metody leksykalnej autor korzystał z metody kolejnych zbliżeń, którą propagował Andrzej Chodubski - polega ona na wiązaniu cech powtarzających się zjawisk w różnych ujęciach teoretycznych ${ }^{48}$. Badanie wiąże dane empiryczne z odniesieniami teoretycznymi i stanowi analizę zarówno ilościową, jak i jakościową. Dokonano doboru jednostek badania według doboru próby celowej ${ }^{49}$. Autor korzystał w tej mierze z dorobku teorii ugruntowanej Anselma Straussa i Barneya Glasera, gdyż - co ujawniono powyżej - uczestniczył w działaniach dociekliwych nie tylko jako obserwator, lecz także jako aktor ${ }^{50}$. Zjawiska i zdarzenia poddane analizie i syntezie obejmują lata 2002-2018. Nie jest to jednak kompleksowe studium ani monograficzne ujęcie tak zarysowanego problemu badawczego; jego przygotowaniem autor dopiero się zajmuje.

\section{DOCIEKLIWI W POLSCE}

W Polsce nie istnieje żaden centralny zbiór zapytań o informację publiczną, nie ma też instytucji, która dysponuje danymi statystycznymi dotyczącymi dostępu do informacji publicznej, choćby o tym, ile zapytań o informację publiczną wpływa rocznie w Polsce. Sytuacji nie zmienia istniejący portal internetowy www.danepubliczne.gov.pl; zamieszczone w nim dane należy uznać za szczątkowe, a istnienie portalu w żaden sposób nie przyczynia się do rzeczywistego wzrostu transparentności działań władzy w Polsce. Taki stan rzeczy utrudnia obiektywne rozpoznanie charakteryzowanego zjawiska. Niemniej nie stanowi to bariery dla próby uchwycenia określanych zjawisk politycznych dzięki podjętemu badaniu. Wiadomo bowiem, że liczba spraw o dostęp do informacji

\footnotetext{
48 A. Chodubski, Wstęp do badań politologicznych, Gdańsk 2005, s. 131.

49 Podstawy statystyki. Podręcznik, red. W. Starzyńska, Warszawa 2009, s. 32-33.

50 Zob. K. Konecki, Studia z metodologii badań jakościowych. Teoria ugruntowana, Warszawa 2000, Przedsiębiorczość.
} 
publicznej w Polsce, kierowanych do Samorządowych Kolegiów Odwoławczych (SKO) i do Wojewódzkich Sądów Administracyjnych (WSA) oraz do Naczelnego Sądu Administracyjnego (NSA), jest bardzo wysoka. Starając się dociec w latach 2016-2017, jaka liczba spraw o dostęp do informacji publicznej była prowadzona przez jednostki samorządu terytorialnego (JST) oraz jakiej materii zagadnień one dotyczyły, autor złożył zapytania, ale uzyskał jedynie częściowe odpowiedzi, bowiem spośród kilku zapytanych podmiotów prawidłową odpowiedź przesłały zaledwie cztery, dając tym samym podstawy do skierowania spraw do SKO. Od tej czynności autor się powstrzymał.

Autor złożył zapytania do: Urzędu Miasta w Słupsku, Urzędu Miasta w Ustce, Urzędu Gminy w Smłodzinie, Urzędu Gminy w Słupsku, Urzędu Gminy w Kobylnicy, Urzędu Miejskiego w Gdańsku, Urzędu Miejskiego w Sopocie, Urzędu Miejskiego w Chojnicach. Uzyskane odpowiedzi nie napawają optymizmem, bowiem po pierwsze urzędnikom brakuje wiedzy, po drugie na tak samo postawione pytanie część urzędów odpowiedziała, część nie, a część zażądała wskazania szczególnego interesu publicznego (Sopot, gmina wiejska Słupsk) ${ }^{51}$. Autor zaś pytał w 2016 r. o: liczbę zapytań o informację publiczną, jaką otrzymał urząd w latach 2002-2015 z rozbiciem na każdy rok; dokładną datę, kiedy urząd otrzymał pierwsze zapytanie o informację publiczną, ze wskazaniem, czego dotyczyło to zapytanie. Analogiczne zapytania autor kierował w 2017 r., zmieniając jedynie zakres dat i wskazując lata 2002-2016. Odpowiedzi od podmiotów, które jej udzieliły, przedstawiono w formie danych ilościowych w tabeli 1 . Choć pojawily się bariery w uzyskaniu odpowiedzi na postawione JST pytania, to należy zauważyć, że niektóre samorządy w Polsce wprowadziły rejestr spraw dotyczących dostępu do informacji publicznej, a część z nich synchronizowała ujawniane dane z portalem danepubliczne.gov.pl. Niestety zbiór danych na wskazanym portalu jest niewielki, choć sam portal miał w zamyśle funkcjonować jako Centralny Rejestr Informacji Publicznej ${ }^{52}$. Pomimo tego wzorcowy przykład rejestru zapytań o dostęp do informacji publicznej funkcjonuje obecnie w Olsztynie ${ }^{53}$ oraz w Słupsku ${ }^{54}$, a podobne w miastach wojewódzkich Polski: Szczecinie ${ }^{55}$, Gdańsku ${ }^{56}$,

51 Wiadomość e-mail z Urzędu Miejskiego w Sopocie do autora, 2 VIII 2016, archiwum autora; wiadomość e-mail z Urzędu Gminy Słupsk, 27 II 2017, archiwum autora.

52 Centralny Rejestr Informacji Publicznej może w Polsce jedynie pełnić rolę scentralizowanego Biuletynu Informacji Publicznej i powielać informacje zawarte w poszczególnych Biuletynach, co nijak ma się do centralnego repozytorium z rejestrem informacji publicznej na wniosek. Zob. A. Gryszczyńska, Centralne Repozytorium Informacji Publicznej, „Kwartalnik Prawa Publicznego” R. 12, 2012, nr 3, w różnych miejscach.

53 Zob. Rejestr wniosków o udostępnienie informacji publicznej, Biuletyn Informacji Publicznej Urzędu Miasta Olsztyna, [online]: http://bip.olsztyn.eu/bip/dokument/340417/rejestr_wnioskow_o_udostepnienie_informacji_publicznej_2018r_/, 10 VI 2018.

54 Zob. Rejestr wniosków o udostępnienie informacji publicznej, [online] http://bip.um.slupsk.pl/udostepnienie_informacji_publicznej/dokumenty/1327.html, 10 VI 2018.

55 Biuletyn Informacji Publicznej Urzędu Miasta Szczecin, Wykaz informacji udostępnianych na wniosek, [online] http://bip.um.szczecin.pl/chapter_131014.asp, 10 VI 2018.

56 Biuletyn Informacji Publicznej Urzędu Miejskiego w Gdańsku, [online] http://bip.gdansk.pl/urzad-miejski/informacja-publiczna?archiwum=rw, 10 VI 2018. 
Gorzowie Wielkopolskim ${ }^{57}$, Wrocławiu ${ }^{58}$, Poznaniu ${ }^{59}$. Rejestru takiego nie prowadziły w 2018 r. inne miasta wojewódzkie, w tym: Bydgoszcz ${ }^{60}$, Białystok ${ }^{61}$, Zielona Góra $^{62}$, Opole ${ }^{63}$, Łódź $^{64}$, Warszawa ${ }^{65}$, Kielce ${ }^{66}, \mathrm{Kraków}^{67}$, Rzeszów ${ }^{68}$. Można uznać, że istotny element, jakim jest ujawnianie i publikowanie na stronach JST rejestru umów cywilno-prawnych, przyczynia się do wzrostu przejrzystości działań władzy - i taki rejestr autor znalazł na większości analizowanych przez siebie stron Biuletynu Informacji Publicznej.

Na drodze zapytań o informację publiczną autor ustalił, że w Gdańsku rejestr liczby zapytań o dostęp do informacji publicznej prowadzi się dopiero od 2013 r., w pozostałych gminach albo wybrakowano dokumentację sprzed 2010 r., albo rejestr zaczęto prowadzić równie późno. Dane wskazują jednak na wzrost zainteresowania obywateli dostępem do informacji publicznej. Ponadto istnieją podstawy ku budowie lub powołaniu centralnego organu, który byłby odpowiedzialny za gromadzenie i opracowywanie informacji dotyczących realizacji prawa dostępu do informacji publicznej w Polsce. Jak widać, w wybranych gminach liczba zapytań była bardzo wysoka, szczególnie w Gdańsku i w Chojnicach, choć Chojnice są miastem mającym zaledwie 40 tys. mieszkańców.

57 Biuletyn Informacji Publicznej Urzędu Miejskiego w Gorzowie Wielkopolskim, [online] http:// bip.wrota.lubuskie.pl/umgorzow/293/Rejestr_wnioskow_o_udostepnienie_informacji_publicznej_ wraz_z_odpowiedziami/, 10 VI 2018.

58 Biuletyn Informacji Publicznej Urzędu Miejskiego Wrocławia, [online] http://bip.um.wroc.pl/infor macje-publiczne/634, 10 VI 2018.

59 Biuletyn Informacji Publicznej Miasta Poznania, [online] http://bip.poznan.pl/bip/rejestr-wnioskow/, 10 VI 2018.

60 Rejestry prowadzone w Urzędzie Miasta Bydgoszczy, [online] http://bip.um.bydgoszcz.pl/na_skroty/rejestry-prowadzone-w-umb/, 10 VI 2018.

${ }^{61}$ Biuletyn Informacji Publicznej Urzędu Miejskiego w Białymstoku, [online] https://www.bip.bialystok.pl/urzad_miejski/dostep_do_informacji_publicznej/udostepnianie-informacji-publicz.html, 10 VI 2018.

62 Biuletyn Informacji Publicznej Urzędu Miasta Zielona Góra, [online] http://bip.zielonagora.pl/83/ Udostepnianie_informacji_publicznej/\#, 10 VI 2018.

63 Biuletyn Informacji Publicznej Miasto Opole, [online] http://www.bip.um.opole.pl/?id=36160, 10 VI 2018.

64 Biuletyn Informacji Publicznej Urząd Miasta Łódź, [online] http://bip.uml.lodz.pl/urzad-miasta/ rejestry-ewidencje-archiwa-w-tym-nieudostepnione-w-bip/, 10 VI 2018.

65 Informacja Publiczna Miasto Stołeczne Warszawa, [online] http://www.um.warszawa.pl/sprawy-urzedowe/udost-pnianie-informacji-publicznej/udost-pnianie-informacji-publicznej-na-wniosek, 10 VI 2018.

66 Biuletyn Informacji Publicznej Miasto Kielce, [online] http://www.bip.kielce.eu/99, 10 VI 2018.

67 Biuletyn Informacji Publicznej Miasto Kraków, [online] https://www.bip.krakow.pl/?sub_dok_ id=13743, 10 VI 2018.

68 Biuletyn Informacji Publicznej Miasta Rzeszowa, [online] http://bip.erzeszow.pl/sprawy-obywatelskie/informacja-publiczna-tekom/udostepnianie-informacji-publicznej-na-wniosek, 10 VI 2018. 
Podobne pytania zadała redakcja portalu zaleze.com: pytała o liczbę wniosków o dostęp do informacji publicznej, które złożono od 1 stycznia 2014 do połowy $2017 \mathrm{r}$. dla gmin: Jedlicze, Rymanów, Staszów, Jasło, Krosno. Podobnie jak we wcześniej analizowanym przypadku, nie wszystkie gminy odpowiedziały w czasie, a władze Krosna w ogóle nie udzieliły odpowiedzi ${ }^{69}$. W tym okresie do urzędu gminy Jedlicze wpłynęły 264 wnioski o udostępnienie informacji publicznej ${ }^{70}$, do gminy Rymanów $-163^{71}$, do gminy Staszów $-272^{72}$. Problem dostępu do informacji publicznej w jednostkach pomocniczych JST jest powszechnie znany, gdyż obywatele wielokrotnie występowali do sądów administracyjnych w sprawie bezczynności rad osiedli, dzielnic i rad sołeckich w zakresie udostępniania informacji publicznej.

Tab. 1. Liczba zapytań o dostęp do informacji publicznej w wybranych gminach Polski w latach 2002-2016

\begin{tabular}{|c|c|c|c|c|}
\hline \multicolumn{4}{|c|}{$\begin{array}{c}\text { Nazwa instytucji otrzymującej zapytanie o informację publiczną oraz liczba zanoto- } \\
\text { wanych zapytań o informację publiczną w latach 2002-2016 }\end{array}$} \\
\hline Lata & $\begin{array}{c}\text { Urząd Miejski } \\
\text { w Chojnicach }\end{array}$ & $\begin{array}{c}\text { Urząd Miasta } \\
\text { Ustka }\end{array}$ & $\begin{array}{c}\text { Urząd Miasta } \\
\text { w Gdańsku }\end{array}$ & $\begin{array}{c}\text { Urząd Gminy } \\
\text { w Kobylnicy }\end{array}$ \\
\hline $2002-2009$ & brak danych & brak danych & brak danych & $\begin{array}{c}\text { dokumentacja } \\
\text { wybrakowana } \\
\text { zgodnie z instruk- } \\
\text { cją kancelaryjną }\end{array}$ \\
\hline 2010 & 1 & brak danych & brak danych & 11 \\
\hline 2011 & 15 & brak danych & brak danych & 13 \\
\hline 2012 & 174 & 38 & brak danych & 21 \\
\hline 2013 & 658 & 64 & 289 & 26 \\
\hline 2014 & 362 & 87 & 330 & 68 \\
\hline 2015 & 1356 & 81 & 476 & 67 \\
\hline 2016 & 395 do 13 VI & - & - & 127 \\
\hline
\end{tabular}

Źródło: opracowanie na podstawie zapytań o informację publiczną wysłanych przez autora, archiwum autora.

69 O co obywatele pytaja urzędy? Lista wniosków o informację publiczna w Jedlczu, Rymanowie... oraz skarga na Prezydenta Krosna, 14 XI 2017, [online] http://www.zaleze.com/o-co-obywatele-pytajaurzedy-lista-wnioskow-o-informacje-publiczna-w-jedliczu-rymanowie-oraz-skarga-na-prezydentakrosna/, 10 VI 2018.

70 Odpowiedź na wniosek z dnia 30 X 2017, [online] https://pl.scribd.com/document/364433519/ Odpowied\%C5\%BA-Na-Wniosek-z-Dnia-30-10-2017-2, 10 VI 2018.

71 Rymanów informacja o ilości wniosków inf. publiczna 2014-2017, [online] https://pl.scribd.com/document/364433879/Rymanow-Informacja-o-Ilo\%C5\%9Bci-Wnioskow-Inf-Publiczna-2014-2017, 10 VI 2018.

72 Odpowiedź na wniosek, [online] https://pl.scribd.com/document/364434218/odpowied\%C5\%BAna-wniosek-1-pdf, 10 VI 2018. 


\section{DOCIEKLIWI I ICH DZIAŁALNOŚĆ}

W zrozumieniu fenomenu wysokiej liczby zapytań o informację publiczną pozwala pomóc obserwacja prasy, która ujawniła, że jeden z dociekliwych, Mariusz Janik, składał do Urzędu Miejskiego w Chojnicach wysoką liczbę zapytań o dostęp do informacji publicznej - kilkadziesiąt dziennie - szczególnie w kwestiach dotyczących burmistrza Chojnic, bowiem od lat pozostawał z nim w osobistym konflikcie, co przekładało się na wydarzenia na scenie politycznej miasta. Pytał $\mathrm{m}$.in. o to, dlaczego burmistrz nie potrafi przyznać się do błędów, ale też: dlaczego urząd miejski jest materialnie w innej epoce, czy władze miasta wybudują pas startowy, aby bezrobotni wylecieli z Chojnic, kiedy władze miasta zorganizują wycieczki po upadłych zakładach, ile ton węgla spala się rocznie w Chojnicach ${ }^{73}$. Janik do niedawna był aktywnym blogerem i jako dociekliwy wskazywał osoby, z którymi współpracuje w zakresie dostępu do informacji publicznej, m.in. posła Kukiz'15 z Bydgoszczy Pawła Skuteckiego ${ }^{74}$. Wcześniej Janik współdziałał z Sojuszem Lewicy Demokratycznej, a nawet był na spotkaniach partii Zmiana, znanej z prorosyjskiego stanowiska. Jego poglądy polityczne można więc określić jako lewicowe, socjalno-liberalne i w jakimś stopniu antysystemowe ${ }^{75}$. W toku działania, pomimo zarzucanej przez władze Miasta Chojnice uciążliwości, Janik zwracał uwagę na poważne niedomagania działalności władz publicznych. Przykładowo w 2016 r. wykazał, że sekretarz Miasta Chojnice Robert Wajlonis uzyskiwał zapomogi, choć osiągał bardzo wysoki dochód, co Janik uznał za skandaliczne ${ }^{76}$. Nadto ujawnił, że sędziowie Sądu Rejonowego w Chojnicach otrzymują zwrot kosztów za dojazd do pracy ${ }^{77}$. Dostęp do informacji publicznej Janik wykorzystał też dla uzyskania informacji o sieci znajomości i powiązaniach lokalnych układów władzy na styku polityki i wymiaru sprawiedliwości, próbując wykazać, że istnieje swoista zmowa tych instytucji przeciwko niemu ${ }^{78}$. Nadto ujawnił niezgodne z prawem działania jednego z komorników sądowych i doprowadził do jego odwołania. Wykorzystując dostęp do informacji publicznej, doprowadził też przed Sąd Komendanta Komendy Policji Powiatowej w Chojnicach ${ }^{79}$.

Innym przykładem dociekliwego może być Radek Sawicki, anarchista ekolog z Chojnic i prezes stowarzyszenia Wspólna Ziemia. Zapytaniami o dostęp do informacji

73 Obywatel pyta, urząd odpowiada, 15 V 2015, [online] http://chojnice24.pl/artykul/20448/obywatelpyta-urzad-odpowiada/, 11 VI 2018.

74 Mariusz Janik i informacja publiczna, [online] http://janikmariusz.blogspot.com/, 11 VI 2018.

75 Rozmowy i wywiady z Mariuszem Janikiem, archiwum autora.

76 Wajlonis bierze Zapomogi Socjalne, 23 II 2017, [online] http://janikmariusz.blogspot.com/2017/02/ wajlonis-bierze-zapomogi-socjalne.html, 11 VI 2018.

77 Sędziowie maja ptacone za dojazd do pracy, II 2017, [online] http://janikmariusz.blogspot. com/2017/02/sedziowie-maja-pacone-za-dojazd-do-pracy.html, 11 VI 2018.

78 Waty sędziego Sporysza cz. 2, 2 II 2017, [online] http://janikmariusz.blogspot.com/2017/02/way-se dziego-sporysza-cz2.html, 11 VI 2018.

79 M. Szymecka, Grzywna dla komendanta Policji, 1 II 2018, [online] http://chojnice24.pl/artykul/ 26511/grzywna-dla-komendanta-policji/, 20 VI 2018. 
publicznej uzyskał dane, które spowodowały wygaszenie mandatu dwóch radnych miejskich w Chojnicach przez wojewodę pomorskiego ${ }^{80}$. Sawicki, podobnie jak Marcin Wałdoch (kojarzony ze środowiskami prawicowymi), byli w Chojnicach w głębokim sporze sądowym z art. $212 \$ 2$ Kodeksu karnego, będącym konsekwencją upubliczniania wcześniej pozyskanej informacji publicznej i wskazywania możliwych działań patologicznych władzy lokalnej w Chojnicach. Proces ów dwaj aktywiści społeczni wygrali, ale po prawie dwóch latach ciężkich batalii na salach sądowych ${ }^{81}$. Zauważa się w literaturze, że już w Europejskiej konwencji praw człowieka z 1950 r. powiązano prawo do informacji z wolnością wyrażania opinii ${ }^{82}$.

Pojedynczych przykładów działalności dociekliwych jest wiele, ale dla egzemplifikacji nasilenia zjawiska w jednym obszarze istotne może być wskazanie Kamila Świętonia, który jako mieszkaniec Dębicy na Podkarpaciu zapytał o oznakowanie miejsc parkingowych dla niepełnosprawnych w Chojnicach. Uzyskał z Urzędu Miejskiego odpowiedź wskazującą na prawidłowe ich oznakowanie i postanowił tę odpowiedź zweryfikować empirycznie, dlatego przyjechał w tej sprawie do Chojnic. Na miejscu okazało się, że urzędnicy skłamali w odpowiedzi na zapytanie o informację publiczną, bowiem miejsca parkingowe nie były prawidłowo oznakowane. Dociekliwy skierował sprawę do prokuratury, wywołując tym falę krytyki wobec władz miasta ze strony lokalnej opozycji politycznej i mediów, które wskazywały na brak wiarygodności miejskiego magistratu ${ }^{83}$.

Do sieci dociekliwych można też zaliczyć organizacje pozarządowe. W Polsce szczególnie aktywna w tym względzie pozostaje Sieć Obywatelska Watchdog Polska. Prowadzi ona wiele akcji obywatelskich, takich jak Monitoring Spółek Komunalnych i Przejrzystość Stanowienia Prawa, które z jednej strony podnoszą transparentność działań władzy publicznej w różnych gminach w Polsce, a z drugiej aktywizują obywateli, którzy swoją działalnością wpisują się w ruch dociekliwych ${ }^{84}$. Sieć Obywatelska ma znaczące osiągnięcia w zakresie budowy społeczeństwa otwartego. Analiza podjęta przez jej działaczy wykazała, że informacje związane ze stanowieniem prawa w Polsce są w znacznej mierze niedostępne bądź niejasne dla obywateli (ok. 66\% informacji) ${ }^{85}$. Sieć Obywatelska prowadzi także poradnię prawną, dzięki której dociekliwi uzyskują wsparcie prawne w działaniach mających na celu uzyskanie informacji publicznej ${ }^{86}$. Choć formalnie dociekliwi nie posiadają lidera, to właśnie Sieć Obywatelska jest wyraźnym koryfeuszem

80 Mandat Eegowskiego do wygaszenia?, 5 II 2016, [online] http://chojnice24.pl/artykul/22014/man dat-legowskiego-do-wygaszenia/0/, 20 VI 2018.

81 A. Wiśniewska, Watdoch nie pomówit burmistrza, 9 XI 2017, [online] http://chojnice24.pl/arty $\mathrm{kul} / 25951 /$ waldoch-nie-pomowil-burmistrza/, 22 VI 2018.

82 Dostęp do informacji publicznej, red. P. Szustakiewicz, Warszawa 2016.

83 A. Wiśniewska, Ktamstwo w kolorze niebieskim, 31 X 2017, [online] http://chojnice24.pl/arty kul/25887/klamstwo-w-kolorze-niebieskim/, 7 VII 2018.

84 Monitoring Spółek Komunalnych, [online] http://spolki.siecobywatelska.pl/, 25 VI 2018.

85 Access Info Europe, [online] https://www.access-info.org/decision-making-transparency/poland, 25 VI 2018.

86 Poradnia Sieci Watchdog, [online] https://porady.siecobywatelska.pl/, 14 VII 2018. 
środowiska. Lider tej organizacji Szymon Osowski daje wyraz swoim sympatiom politycznym poprzez przyznawanie się do relacji łączących jego organizację z George'em Sorosem oraz aktywny udział w walce politycznej wokół sporu o rolę i miejsce władzy sądowniczej w Polsce ${ }^{87}$.

\section{SKANDALE POLITYCZNE I BURZENIE WIZERUNKU}

Dostęp do informacji publicznej wiąże się z upublicznianiem, a tym samym z jawnością działań, szczególnie naruszania norm społecznych i prawnych, przed opinią publiczną, co może stać się zaczynem skandali politycznych. Dzięki dostępowi do informacji publicznej dociekliwi mogą inicjować skandale finansowe, skandale o podłożu politycznym itd ${ }^{88}$ Informacja publiczna nie jest w Polsce narzędziem, które mogłoby w pełni zapobiec na przykład próbie dyskredytacji osób publicznych. Każdy wniosek kierowany do urzędów administracji publicznej przez osoby fizyczne nie staje się bowiem dokumentem urzędowym ${ }^{89}$. Interesujące są sprawy, kiedy to albo dla nadszarpnięcia wizerunku, albo z autentycznej troski o sprawy publiczne, a być może i z obu przyczyn, dociekliwi składają zapytania o wykształcenie osoby pełniącej funkcję publiczną. W takich przypadkach organ ma obowiązek ujawnić żądane informacje, nawet jeśli wykształcenie nie wiąże się z kwalifikacjami wymaganymi do pełnienia danej funk$\mathrm{cji}^{90}$. Jest to przykład istotny dla zrozumienia, jak w tym zakresie dostęp do informacji publicznej może dezawuować osobę, która pełni funkcję publiczną, ale nie podaje do wiadomości publicznej swojego wykształcenia.

\section{GRUPY INTERESU I KONCENTRACJA WŁADZY}

Problemy z udostępnianiem informacji publicznej w Polsce występują nawet w Trybunale Konstytucyjnym ${ }^{91}$, a fakt ich ujawnienia wzmacnia konflikty na scenie politycznej. W Polsce samorządowej jest wiele przestrzeni, które podlegają dogłębnej kontroli dociekliwych. Przykładem może być próba uzyskania od magistratu Gdyni informacji o zasadach przyznawania nagród w urzędzie, bowiem dociekliwi w tej sprawie

\footnotetext{
Szymon Osowski, [online] https://web.facebook.com/osowski.szymon, 14 VII 2018.

Zob. J.B. Thompson, Skandal polityczny. Wtadza i jej jawność w epoce medialnej, przeł. M. Habura, Warszawa 2010.

89 D. Frey, Doniesienia do urzędu nie sq informacja publiczna, „Rzeczpospolita” 2016, 9 VI, [online] http://www.rp.pl/W-sadzie-i-urzedzie/306099966-Doniesienia-do-urzedu-nie-sa-informacjapubliczna.html, 22 VI 2018.

90 Wyrok Wojewódzkiego Sądu Administracyjnego w Gorzowie Wielkopolskim, 24 V 2017, sygn. II $\mathrm{SAB} /$ Go $1 / 17$.

91 M. Pach, Trybunat kasuje obywatela, „Rzeczpospolita” 2018, 23 III, [online] http://www.rp.pl/Opinie/303239984-Trybunal-kasuje-obywatela---Maciej-Pach-o-ignorowaniu-przez-TK-wnioskow-oudostepnienie-informacji-publicznej.html, 22 VI 2018.
} 
podejrzewają, że w urzędzie istniał system premiowania osób, które wykazywały ideologiczną zgodność z lokalną władzą polityczną ${ }^{92}$. Podobne podejrzenia wobec lokalnej władzy miała w Chojnicach radna, a zarazem nauczycielka Marzenna Osowicka, która starała się uzyskać od dyrekcji jednej z placówek oświatowych informacje o trybie przyznawania nagród dla nauczycieli ${ }^{93}$. Podobne wątpliwości zgłaszano wobec ujawnienia podstaw przyznawania nagród w Ministerstwie Cyfryzacji w okresie rządów minister Anny Streżyńskiej ${ }^{94}$ oraz w wielu innych miejscach w Polsce. Dowodem na to może być wyrok WSA z Rzeszowa, w którym sąd zgadza się co do interpretacji, że informacja o nagrodach pracowników samorządowych to informacja publiczna ${ }^{95}$. Oczywistym jest, że brak jawności przyznawania nagród w administracji publicznej sugeruje budowanie nieformalnych zależności, systemu dojść i znajomości oraz zadowoleniu władzy z klaki.

Innym przykładem wykorzystania prawa do informacji publicznej w celu monitoringu działań władzy samorządowej było zapytanie, jakie jeden z dociekliwych złożył do burmistrz Czerska. Pytał o wyciąg z listy obecności w pracy jej doradcy od początku jego pracy. Burmistrz i SKO odmówili żądanej informacji, ale WSA w Gdańsku przyznał dociekliwemu prawo jej uzyskania i nakazał organowi wydanie informacji ${ }^{96}$. W całej sprawie chodziło o działanie polityczne jednego z redaktorów lokalnej prasy, który na łamach swojego tytułu ujawniał kompromitujące władzę w Czersku informacje. Jak widać, w celu dyskredytacji władzy samorządowej w oczach opinii publicznej posłużył się skutecznie prawem dostępu do informacji publicznej. Pokłosiem tego działania, jak można domniemywać, była rezygnacja doradcy burmistrza Czerska z funkcji ${ }^{97}$.

Brak dostępu do informacji publicznej może budzić poważne wątpliwości co do uczciwości władzy politycznej, która przykładowo ukrywała dane ekspertów dokonujących analiz likwidacji Otwartych Funduszy Emerytalnych dla kancelarii prezydenta RP Bronisława Komorowskiego ${ }^{98}$. Władza polityczna często powołuje się na analizy eksperckie dla uzyskania swoich celów, a więc takiej decyzji politycznej zgodnej z jej wizją. Podobny problem dotyczy polityki jawności w świecie nauki, prawo bowiem chro-

92 P. Pieńkosz, Dostęp do informacji publicznej ma być petny, „Dziennik Gazeta Prawna” 2016, 6 VIII, [online] http://prawo.gazetaprawna.pl/artykuly/964937,dostep-do-informacji-publicznej-ma-bycpelny.html, 25 VI 2018.

93 A. Wiśniewska, Potajanki od dyrektorki i dla dyrektorki, 14 XII 2017, [online] http://chojnice24.pl/ artykul/26215/polajanki-od-dyrektorki-i-dla-dyrektorki/15/, 25 VI 2018.

94 E. Ivanova, Nagrody w miniesterstwie: kwoty jawne, nazwiska tajne, „Dziennik Gazeta Prawna” 2016, 9 VI, [online] http://prawo.gazetaprawna.pl/artykuly/950412,dostep-do-informacji-publicznejnaqgrody-w-ministerstwie.html, 27 VI 2018.

Wyrok Wojewódzkiego Sądu Administracyjnego w Rzeszowie, 19 V 2017, sygn. II SAB/Rz 11/17.

Wyrok Wojewódzkiego Sądu Administracyjnego w Gdańsku, 5 IV 2017, sygn. II SA/Gd 7/17.

97 A. Klaman, Adam Domiński już się wycofat. Nie będzie brat ztotówek z urzędu, „Gazeta Pomorska” 2017, 12 IV, [online] http://www.pomorska.pl/wiadomosci/chojnice/a/adam-dominski-juz-siewycofal-nie-bedzie-bral-zlotowek-z-urzedu,11981840/, 7 VII 2018.

B. Wilk, Wtadza wciąż ukrywa personalia osób, którym ptaci, „Dziennik Gazeta Prawna” 2016, 18 VII, [online] http://prawo.gazetaprawna.pl/artykuly/960701,wladza-wciaz-ukrywa-personalia-osobktorym-placi.html, 27 VI 2018. 
ni dane ekspertów, którzy oceniają wnioski w postępowaniach o prestiżowe granty, np. z Narodowego Centrum Nauki, z czym nie zgadzają się poszczególni przedstawiciele tego świata, wskazujący na niesprawiedliwą ocenę i chęć jej konfrontacji z rzeczywistymi kompetencjami osób oceniających ich wnioski grantowe. Jednak prawo przyznaje prymat ochronie bezstronności ekspertów na podstawie ustawy o zasadach finansowania nauki"

\section{KORUPCJA}

Przypadek Korony Kielce i fakt przejęcia w niej większości udziałów przez prywatnego przedsiębiorcę jest istotny ze względu na transparentność działań publicznych. Przed 2017 r. spółka była w większości własnością gminy miejskiej i otrzymywała miejskie dotacje, co sytuowało ją wśród podmiotów, które podlegają prawu o dostępie do informacji publicznej. Przejęcie spółki przez podmiot prywatny uniemożliwiło jednemu z dociekliwych uzyskanie wiadomości o celowości wydatkowania środków publicznych w Koronie Kielce w latach 2010-2016. Sytuacja ta jest zgodna z obowiązującym prawem, wskazuje jednak możliwą ścieżkę obejścia prawa o dostępie do informacji publicznej poprzez zmianę struktury własności spółek komunalnych ${ }^{100}$. Obecne regulacje prawne umożliwiają też nadawanie informacji publicznej klauzuli poufności, jak w przypadku, kiedy prezydent Warszawy Hanna Gronkiewicz-Waltz nadała klauzulę tajności przedwstępnej umowie o prywatyzacji Stołecznego Przedsiębiorstwa Energetyki Cieplnej S.A. ${ }^{101}$ Proces ten może ułatwiać utrzymywanie władzy i kontrolowanie dyskursu politycznego, jednocześnie przyczyniając się do narastania praktyk korupcjogennych.

\section{TRANSPARENTNOŚĆ KONTRA POUFNOŚĆ - MOŻLIWOŚCI DESTABILIZACJI ŁADU PAŃSTWOWEGO}

Interesująca była odmowa na zapytanie o dostęp do informacji publicznej, którą otrzymał Stefan Hambura. Ubiegal się on o dostęp do akt sprawy prowadzonej przez prokuraturę przeciwko Tomaszowi Arabskiemu, którego w ocenie Hambury obciążały zeznania składane przed sądem przez Donalda Tuska w 2018 r. Hambura sugerował, że odmowa dostępu do tych informacji może być wynikiem zmowy politycznej ${ }^{102}$.

99 Wyrok Naczelnego Sądu Administracyjnego w Warszawie, 1 II 2018, sygn. I OSK 699/16.

100 D. Frey, Klub sportowy nie musiat ujawnic, ile dostat od miasta, „Rzeczpospolita” 2018, 22 II, [online] http://www.rp.pl/Finanse/302229974-Klub-sportowy-nie-musi-ujawnic-ile-dostal-od-miasta.html, 22 VI 2018.

101 R. Górski, Jawne przez tajne, „Wprost” 2017, 5 XI, [online] https://www.wprost.pl/tygodnik/10084660/Jawne-przez-tajne.html, 18 VI 2018.

102 Hambura: PiS obawia się pewnych wątków ws. Katastrofy smoleńskiej, „Rzeczpospolita” 2018, 25 V, [online] http://archiwum.rp.pl/artykul/1374206-Rzeczpospolita-TV:-Hambura:-PiS-obawia-siepewnych-watkow-ws-katastrofy.html, 20 VI 2018. 
Zagrożenia dla ładu politycznego i bezpieczeństwa państwa można też dostrzec w takich sprawach, jak ta z 2017 r., kiedy jeden z obywateli wnioskowal do Biura Ochrony Rządu (BOR) o informacje na temat zakresu obowiązków szefa BOR i jego zastępców. Szef BOR odmówił ich wydania, a jego stanowisko podzielił WSA w Warszawie wyrokiem z 1 grudnia. W tym przypadku dociekliwy obywatel próbował uzyskać informację do użytku w innym procesie przeciwko szefowi BOR, na okoliczność mobbingu i dyskryminacji ${ }^{103}$.

Działaniem mającym wymiar polityczny było zapytanie przedstawicieli jednej z fundacji w Polsce skierowane do Agencji Bezpieczeństwa Wewnętrznego (ABW). Pytano o to, czy ta przekazywała jakiekolwiek informacje do Agencji Bezpieczeństwa Narodowego USA w ramach programów takich jak ORANGECRUSH lub OAKSTAR, czy jest członkiem partnerstwa BUFFALOGREEN oraz czy otrzymywała jakieś środki finansowe od NSA ${ }^{104}$. Informacje o możliwości istnienia takich relacji ujawnił jeden z najszerzej na świecie rozpoznawanych sygnalistów, czyli Edward Snowden ${ }^{105}$. W tej sprawie organy odmawiające prawa dostępu do informacji publicznej powoływały się m.in. na skomplikowaną sytuację polityczną na świecie i możliwość szkód, jakie może przynieść Rzeczypospolitej udzielenie odpowiedzi, jednocześnie kwalifikując te informacje jako niejawne. Sąd zaś przede wszystkim wykazał, że dla podjęcia decyzji o ujawnieniu bądź niejawności danej informacji publicznej kluczowe jest posiadanie przez sąd wiedzy o działalności służb specjalnych w przedmiotowym zakresie. Takich informacji $\mathrm{ABW}$ nie udzieliła nawet sądowi ${ }^{106}$.

\section{PARALIŻ INSTYTUCJI}

Komentatorzy podkreślają, że obywatele mogą nadużywać prawa dostępu do informacji publicznej, a w polskim ustawodawstwie brakuje możliwości przeciwdziałania takim sytuacjom, co zmusza urzędników do odpowiedzi na kuriozalne pytania. Wskazuje się przykłady takich państw jak Australia, gdzie wprowadza się pojęcie dokuczliwego obywatela, Szwajcaria, gdzie instytucje publiczne mają prawo odmówić udostępnienia informacji, gdyby wymagało to nieproporcjonalnie dużego nakładu pracy, czy Wielka Brytania, gdzie odmowa może być podyktowana uporczywością składania zapytań o takiej samej treści. W irlandzkiej ustawie wyklucza się zaś możliwość udzielania odpowiedzi na pytania niepoważne i dokuczliwe ${ }^{107}$. W Polsce, co wskazano powyżej, prawo dostępu do informacji publicznej jest wykorzystywane

103 Wyrok Wojewódzkiego Sądu Administracyjnego w Warszawie, 1 XII 2017, sygn. II SA/Wa 596/17.

104 Wyrok Naczelnego Sądu Administracyjnego w Warszawie, 8 III 2017, sygn. I OSK 1312/15.

105 Zob. Orange Crush, 13 V 2014, [online] https://edwardsnowden.com/2014/06/13/orange-crush/, 7 VII 2018.

106 Wyrok Naczelnego Sądu Administracyjnego w Warszawie, 8 III 2017, sygn. I OSK 1312/15.

107 M. Niziołek, Ochrona przed nadużywaniem prawa do informacji publicznej, „Rzeczpospolita” 2017, 5 XII, [online] http://www.rp.pl/Urzednicy/312059991-Ochrona-przed-naduzywaniem-prawa-doinformacji-publicznej.html, 10 VI 2018. 
przez dociekliwych, co buduje pozory nadużywania prawa, jak określają tę sytuację polityczną prawnicy. Niemniej NSA w sytuacjach, które rozpoznaje jako paraliżowanie instytucji publicznych przez dociekliwych, usiłuje swoimi wyrokami nie sankcjonować nadużywania prawa, nie nakładając kar na urzędy w przypadku, kiedy te nie są w stanie odpowiedzieć obywatelom w określonym ustawą czasie. Nadto prawnicy stoją na stanowisku, że osoby, które spełniają kryterium materialne i mogą ubiegać się o dostęp do sądu bez ponoszenia kosztu 100 złotych od skargi do WSA, będą sami lub z pomocą osób trzecich wykorzystywać swoje położenie ${ }^{108}$. Oceniono, że [...] niewątpliwie znajdzie się określona grupa podmiotów, które spróbuja uczynić z tej możliwości dodatkowe, o ile nie podstawowe źródto dochodu ${ }^{109}$. Niemniej orzecznictwo zmierza do uchylania się od wypłaty wynagrodzenia za profesjonalnego pełnomocnika występującego w imieniu osoby, która notorycznie ubiega się o dostęp do informacji publicznej, co rodzi podejrzenia co do uczciwości i postawy etycznej adwokatów ${ }^{110}$. Samorządy z rzeczywistą albo jedynie urojoną uporczywością, którą lokalni włodarze zwykli nazywać stręczycielstwem lub stalkingiem wobec nich i urzędników, najczęściej w sytuacjach, kiedy dociekliwi byli ich oponentami politycznymi, próbowały radzić sobie w różny sposób, m.in. poprzez przymuszanie obywateli do odbioru odpowiedzi na informację publiczną w urzędzie i to w wyznaczonym miejscu, co oczywiście było niezgodne z prawem ${ }^{111}$.

Wokół dostępu do informacji publicznej w Polsce powstał przemysł, na którym zarabiają nieuczciwe kancelarie adwokackie i poszczególni przedstawiciele tego zawodu. Brak kary za nadużywanie prawa sprawil, że prawnicy wystawiali „słupy”, które lawinowo kierowały zapytania o informację publiczną, prawnicy zaś na tej nieuczciwej praktyce zarabiali od kilkuset do kilku tysięcy złotych od sprawy jako pełnomocnicy osoby skarżącej ${ }^{112}$. Nadużycia prawa, rozumianego jako działanie niezgodne z celem, dla którego ustanowiono dane prawo ${ }^{113}$, w tym sensie dopuszczali się obywatele.

Niestety prawniczych propozycji karania za „uporczywość” czy próby paraliżu państwa przez domagających się dostępu do informacji publicznej nie można oceniać pozytywnie. Zawsze bowiem pozostaje zbyt duża doza uznaniowości sędziów wobec przedmiotowej sprawy. Dowodem na to może być sam prawniczy postulat, który sprowadza

108 M. Kowalski, Nadużycie prawa..., s. 56-57.

109 Tamże, s. 58.

110 D. Frey, Sąd: adwokat nie dostanie zwrotu kosztów za występowanie w podobnych sprawach, „Rzeczpospolita" 2018, 17 IV, [online] http://www.rp.pl/Adwokaci/304179932-Sad-adwokat-nie-dostaniezwrotu-kosztow-za-wystepowanie-w-podobnych-sprawach.html, 20 VI 2018.

111 M. Suchodolska, Informacja publiczna do odbioru w urzędzie, „Dziennik Gazeta Prawna” 2018, $16 \mathrm{~V}$, [online] http://serwisy.gazetaprawna.pl/samorzad/artykuly/1123985,jawnosc-informacjapubliczna-w-urzedzie-w-gminie-poswietne.html, 25 VI 2018.

112 D. Frey, Biznes prawników i klientów na skargach ws. informacji publicznej, „Rzeczpospolita” 2016, $11 \mathrm{~V}$, [online] http://www.rp.pl/W-sadzie-i-urzedzie/305109894-Biznes-prawnikow-i-klientow-naskargach-ws-informacji-publicznej.html, 10 VI 2018.

113 M. Kowalski, Nadużcie prawa..., s. 51. 
się do zgody unikania przez sądy formalizmu prawniczego na rzecz stosowania tzw. argumentacyjnej metody orzekania.

\section{WEKTORY PRZEMIAN}

W Polsce ewolucja prawa dostępu do informacji publicznej jest możliwa z przyczyn politycznych, bowiem minister Mariusz Kamiński próbował już przeforsować ustawę o jawności życia publicznego, do czego dotąd nie doszło. Środowiska dociekliwych najbardziej oburzyło wprowadzenie kategorii obywatela „uporczywego”, który w ocenie instytucji publicznych składa wnioski o dostęp do informacji publicznej w sposób uporczywy. Taka instytucja znalazła się w projekcie nowej ustawy, jednak została z niego usunięta po licznych protestach ${ }^{114}$. W przyszłości dostęp do informacji publicznej powinien objąć także dane korporacyjne, w szczególności przedsiębiorstw działających na skalę ogólnoświatową, bowiem ich transgraniczny charakter aktywności z zasady sprzyja unikaniu zobowiązań społecznych (w tym podatkowych).

W 2017 r. minister Mariusz Kamiński, koordynator służb specjalnych, upublicznił projekt ustawy o jawności życia publicznego, który spotkał się z szeroką krytyką opinii publicznej, w tym organizacji pozarządowych monitorujących życie publiczne na podstawie ustawy o dostępie do informacji publicznej ${ }^{115}$. Swoje uwagi zgłosiło w trakcie konsultacji publicznych ponad 200 podmiotów, a treść ich uwag wskazuje, że przynależą do ruchu dociekliwych. Proponowana ustawa o jawności życia publicznego ma scalić trzy ustawy: o dostępie do informacji publicznej, o ograniczeniu prowadzenia działalności gospodarczej przez osoby pełniące funkcje publiczne oraz o działalności lobbingowej w procesie stanowienia prawa. Jedną ze zgłaszanych uwag był sprzeciw wobec proponowanego obowiązku utrwalania przebiegu spotkań jednostek pomocniczych samorządów, czyli rad osiedli i zebrań wiejskich ${ }^{116}$. Szczególny zaś protest, jak już wspomniano, wzbudziły propozycje wprowadzenia instytucji „uporczywego obywatela”, co według projektodawcy miało umożliwić unikanie paraliżu instytucji publicznych.

\section{ZAKOŃCZENIE}

W toku badania potwierdzono hipotezę stanowiącą przypuszczenie, że wokół realizacji prawa dostępu do informacji publicznej ujawnił się w Polsce nowy ruch społeczny

114 L. Jaworski, P. Sikora, Nie odpuszczajmy zmian w informacji publicznej. Okietznać trzeba uporczywośc, „Dziennik Gazeta Prawna” 2017, 17 XI, [online] https://edgp.gazetaprawna.pl/e-wydanie/1156,17-listopada-2017/5194,Tygodnik-Gazeta-Prawna/657111,Nie-odpuszczajmy-zmian-w-informacji-pu blicznej--Okielznac-trzeba-uporczywosc.html, 25 VI 2018.

115 Ustawa o jawności życia publicznego, Rządowe Centrum Legislacji, [online] https://legislacja.rcl.gov. $\mathrm{pl} /$ projekt/12304351, 17 VII 2018.

116 P. Sitniewski, Fundacja JAWNOSC.PL, [online] https://legislacja.rcl.gov.pl/docs//2/12304351/124 65407/12465410/dokument314990.pdf, 17 VII 2018. 
dociekliwych. Potwierdzono także hipotezę pomocniczą stanowiącą przypuszczenie, że dostęp do informacji publicznej w Polsce jest wykorzystywany w walce politycznej. Wnioski są następujące:

1. Wykorzystanie przez badacza życia politycznego narzędzi związanych z korzystaniem z prawa dostępu do informacji publicznej umożliwia uzyskanie danych pozwalających na pomiar partycypacji politycznej.

2. Dociekliwi nie są ruchem antysystemowym, dążą do zmiany politycznej, ale nie do zmiany systemu politycznego.

3. Częstokroć celami działalności dociekliwych są interes społeczny i usprawnienie działalności instytucji publicznych, co nie wyklucza wykorzystania efektów działalności do walki politycznej z rządzącymi, przedstawianymi jako niekompetentni.

4. Należy postulować prawo obowiązujące wszystkie polskie JST do publikowania rejestru zapytań o dostęp do informacji publicznej.

5. Dociekliwi tworzą własne publikatory o podejmowanych działaniach, co umożliwia im przekraczanie w dobie informatyzacji bariery dostępu do opinii publicznej, którą wyznaczają tradycyjnie rozumiane media.

6. Dociekliwi zderzają się z postawami niechętnymi wobec idei społeczeństwa otwartego, transparentności i jawności życia publicznego. Jest to problem mentalny osób zatrudnionych w instytucjach publicznych.

7. Uwarunkowania prawne stawiają indywidualnych obywateli w procesie uzyskiwania informacji publicznej na równi z dziennikarzami, przedstawicielami mediów.

8. Pomimo prymatu zasady jawności życia publicznego dostępowi do informacji publicznej będą się wymykać rozmaite aspekty działalności służb specjalnych, bowiem te bez ponoszenia sankcji odmawiają sądom dostępu do stosownej dokumentacji pozwalającej ustalić, czy żądane przez obywateli informacje są informacjami niejawnymi. $Z$ jednej strony może to chronić instytucje państwa przed nadużywaniem prawa dostępu do informacji publicznej oraz przed wykorzystaniem jej przez służby i obywateli państw wrogich, z drugiej zaś takie praktyki ograniczają i podważają mechanizmy demokratycznego państwa, w tym zasadę jawności życia publicznego.

9. Prawo dostępu do informacji publicznej daje dociekliwym możliwość realizacji celów politycznych dzięki takim działaniom, jak: wywoływanie skandali; burzenie wizerunków osób publicznych i instytucji publicznych; ukazywanie praktyk korupcyjnych, aktywności elit w zakresie funkcjonowania grup interesów i nadmiernej koncentracji władzy; wzmacnianie transparentności działań władzy publicznej i polityków; umacnianie podmiotowości politycznej; wzmacnianie społeczeństwa obywatelskiego, ale i możliwej destabilizacji państwa zarówno na arenie krajowej, jak i międzynarodowej; ukazywanie problemów odnoszących się do pojęcia sprawiedliwości społecznej oraz dystrybucji dóbr publicznych; ukazywanie patologii życia publicznego (w tym nepotyzmu, kleptokracji, systemu dojść i znajomości, ignorancji, hipokryzji władzy, a nawet zwyczajnych 
kłamstw przedstawianych jako urzędowe prawdy); paraliż instytucji publicznych; tworzenie grup o charakterze przestępczym, które czerpią zyski z nadużywania prawa i przy tym wpływania na decyzje polityczne we własnym interesie.

10. Dociekliwi to ruch osób o bardzo różnych afiliacjach ideologicznych, których wspólnym mianownikiem jest idea transparentności.

Konkludując, należy uznać, że formuła dostępu do informacji publicznej w Polsce wypływa z pobudek liberalnych, które jednak pozostawiają wiele miejsca dla działalności powodowanej złą wolą polityczną, ukierunkowaną nie na interes społeczny, ale na uzyskanie określonych celów danych grup.

Pomimo tak zakreślonego obszaru badawczego niniejsze studium ma jedynie charakter wycinkowy. Autor prowadzi jednak w tym zakresie studia zmierzające do ujęcia monograficznego. Jawność i transparentność życia publicznego sprzyjają demokracji i wzmacniają proces jej konsolidacji oraz przyczyniają się do budowy społeczeństwa obywatelskiego, ale jawność życia publicznego nieodparcie stoi w kontrze do życia gospodarczego, które kieruje się zasadą tajności i poufności, a świat silnie zglobalizowany niesie za sobą tę konsekwencję, że polityka jest nierozerwalnie związana z życiem gospodarczym. Od tego więc, jak współczesne społeczeństwa poradzą sobie z tym napięciem/kolizją między tajnością - poufnością a wymogami transparentności życia publicznego, zależeć będzie ich powodzenie.

\section{BIBLIOGRAFIA}

Access Info Europe, [online] https://www.access-info.org/decision-making-transparency/poland. Beck U., Wtadza i przeciwwtadza w epoce globalnej. Nowa ekonomia polityki światowej, przeł. J. Łoziński, Warszawa 2005, Humanistyka Europejska.

Bidziński M., Chmaj M., Szustakiewicz P., Ustawa o dostępie do informacji publicznej. Komentarz, Warszawa 2018.

Biuletyn Informacji Publicznej Urząd Miasta Łódź, [online] http://bip.uml.lodz.pl/ urzad-miasta/rejestry-ewidencje-archiwa-w-tym-nieudostepnione-w-bip/.

Biuletyn Informacji Publicznej Miasta Poznania, [online] http://bip.poznan.pl/bip/rejestrwnioskow/.

Biuletyn Informacji Publicznej Miasta Rzeszowa, [online] http://bip.erzeszow.pl/sprawy-oby watelskie/informacja-publiczna-tekom/udostepnianie-informacji-publicznej-na-wniosek.

Biuletyn Informacji Publicznej Urzędu Miasta Szczecin, Wykaz informacji udostępnianych na wniosek, [online] http://bip.um.szczecin.pl/chapter_131014.asp.

Biuletyn Informacji Publicznej Urzędu Miasta Zielona Góra, [online] http://bip.zielonagora. pl/83/Udostepnianie_informacji_publicznej/\#.

Biuletyn Informacji Publicznej Miasto Kielce, [online] http://www.bip.kielce.eu/99.

Biuletyn Informacji Publicznej Miasto Kraków, [online] https://www.bip.krakow.pl/?sub_ dok id $=13743$.

Biuletyn Informacji Publicznej Miasto Opole, [online] http://www.bip.um.opole.pl/?id=36160. 
Biuletyn Informacji Publicznej Urzędu Miejskiego w Białymstoku, [online] https://www.bip. bialystok.pl/urzad_miejski/dostep_do_informacji_publicznej/udostepnianie-informacji-publicz.html.

Biuletyn Informacji Publicznej Urzędu Miejskiego w Gdańsku, [online] http://bip.gdansk.pl/ urzad-miejski/informacja-publiczna?archiwum =rw.

Biuletyn Informacji Publicznej Urzędu Miejskiego w Gorzowie Wielkopolskim, [online] http://bip.wrota.lubuskie.pl/umgorzow/293/Rejestr_wnioskow_o_udostepnienie_informacji_publicznej_wraz_z_odpowiedziami/.

Biuletyn Informacji Publicznej Urzędu Miejskiego Wrocławia, [online] http://bip.um.wroc.pl/ informacje-publiczne/634.

Castells M., Koniec tysiąclecia, przeł. J. Stawiński, S. Szymański, red. M. Marody, Warszawa 2009.

Castells M., Spoteczeństwo sieci, przeł. M. Marody i in., red. M. Marody, Warszawa 2011.

Chodubski A., Wstęp do badań politologicznych, Gdańsk 2005.

Della Porta D., Diani M., Ruchy spoteczne. Wprowadzenie, przeł. A. Sadza, Kraków 2009, Politika.

Demczuk A., Dostęp do informacji publicznej w Polsce. Analiza krytyczna, „Teka Komitetu Politologii Stosunków Międzynarodowych” 2010, nr 5.

Dostęp do informacji publicznej, red. P. Szustakiewicz, Warszawa 2016.

Dostęp do informacji publicznej $w$ Polsce i w Europie. Wybrane zagadnienia prawne, red. E. Pierzchała, M. Woźniak, Opole 2010.

Dostęp do informacji publicznej w praktyce samorzadu terytorialnego. Konferencja, 19 czerwca 2015 r., red. S. Jakubczak, Warszawa 2015.

Europejska konwencja praw cztowieka, [online] https://www.echr.coe.int/Documents/Convention_POL.pdf.

Frey D., Biznes prawników i klientów na skargach ws. informacji publicznej, „Rzeczpospolita" 2016, $11 \mathrm{~V}$, [online] http://www.rp.pl/W-sadzie-i-urzedzie/305109894-Biznes-praw nikow-i-klientow-na-skargach-ws-informacji-publicznej.html.

Frey D., Doniesienia do urzędu nie sa informacja publiczna, , Rzeczpospolita” 2016, 9 VI, [online] http://www.rp.pl/W-sadzie-i-urzedzie/306099966-Doniesienia-do-urzedu-nie-sainformacja-publiczna.html.

Frey D., Klub sportowy nie musiat ujawnić, ile dostat od miasta, „Rzeczpospolita” 2018, 22 II, [online] http://www.rp.pl/Finanse/302229974-Klub-sportowy-nie-musi-ujawnic-ile-dostalod-miasta.html.

Frey D., Nadawca maila nie musi sprawdzać doręczenia, „Rzeczpospolita” 2017, 28 IV, [online] http://www.archiwum.rp.pl/artykul/1346258-Nadawca-maila-nie-musi-sprawdzacdoreczenia.html.

Frey D., Sąd: adwokat nie dostanie zwrotu kosztów za wystęowanie w podobnych sprawach, „Rzeczpospolita” 2018, 17 IV, [online] http://www.rp.pl/Adwokaci/304179932-Sad-adwokat-nie-dostanie-zwrotu-kosztow-za-wystepowanie-w-podobnych-sprawach.html.

Górski R., Jawne przez tajne, „Wprost” 2017, 5 XI, [online] https://www.wprost.pl/tygodnik/10084660/Jawne-przez-tajne.html. 
Gryszczyńska A., Centralne Repozytorium Informacji Publicznej, „Kwartalnik Prawa Publicznego" R. 12, 2012, nr 3.

Hambura: PiS obawia sie pewnych wątków ws. Katastrofy smoleńskiej, „Rzeczpospolita” 2018, $25 \mathrm{~V}$, [online] http://archiwum.rp.pl/artykul/1374206-Rzeczpospolita-TV:-Hambura:PiS-obawia-sie-pewnych-watkow-ws-katastrofy.html.

Informacja Publiczna Miasto Stołeczne Warszawa, [online] http://www.um.warszawa.pl/sprawyurzedowe/udost-pnianie-informacji-publicznej/udost-pnianie-informacji-publicznej-nawniosek.

Ivanova E., Nagrody w ministerstwie: kwoty jawne, nazwiska tajne, „Dziennik Gazeta Prawna" 2016, 9 VI, [online] http://prawo.gazetaprawna.pl/artykuly/950412,dostep-do-infor macji-publicznej-naqgrody-w-ministerstwie.html.

Jaworski L., Sikora P., Nie odpuszczajmy zmian w informacji publicznej. Okietznać trzeba uporczywość, „Dziennik Gazeta Prawna” 2017, 17 XI, [online] https://edgp.gazetaprawna.pl/ e-wydanie/1156,17-listopada-2017/5194,Tygodnik-Gazeta-Prawna/657111,Nie-odpusz czajmy-zmian-w-informacji-publicznej-Okielznac-trzeba-uporczywosc.html.

Jóźwiak Z., Przetomowy wyrok $w$ sprawie informacji publicznej. Za prace przy anonimizacji danych należy się zaptata, „Dziennik Gazeta Prawna” 2016, 9 IX, [online] http://prawo.gazetaprawna.pl/artykuly/974540,informacja-publiczna-za-prace-przy-anonimizacji-danychnalezy-sie-zaplata.html.

Klaman A., Adam Domiński już się wycofat. Nie będzie brat ztotówek z urzędu, „Gazeta Pomorska” 2017, 12 IV, [online] http://www.pomorska.pl/wiadomosci/chojnice/a/adam-dominskijuz-sie-wycofal-nie-bedzie-bral-zlotowek-z-urzedu,11981840/.

Konecki K., Studia z metodologii badań jakościowych. Teoria ugruntowana, Warszawa 2000, Przedsiębiorczość.

Konstytucja Rzeczypospolitej Polskiej z dnia 2 kwietnia 1997 r. uchwalona przez Zgromadzenie Narodowe w dniu 2 kwietnia 1997 r., przyjęta przez Naród w referendum konstytucyjnym $w$ dniu 25 maja 1997 r., podpisana przez Prezydenta Rzeczypospolitej Polskiej w dniu 16 lipca 1997 r., Dz.U. 1997, nr 78, poz. 483.

Kowalski M., Nadużycie prawa do informacji publicznej, „Zeszyty Naukowe Sądownictwa Administracyjnego" R. 12, 2016, nr 2(65).

Lakomy M., Cyberprzestrzeń jako nowy wymiar rywalizacji i wspótpracy państw, Katowice 2015, Prace Naukowe Uniwersytetu Ślaskiego w Katowicach, nr 3293.

Lyotard J.-F., Kondycja ponowoczesna. Raport o stanie wiedzy, przeł. M. Kowalska, J. Migasiński, Warszawa 1997.

Malendowicz P., Ruchy spoteczne i myśl polityczna - co, jak i po co badać?, „Polityka i Społeczeństwo" 2016, nr 4(14), https://doi.org/10.15584/polispol.2016.4.1.

Mandat Eegowskiego do wygaszenia?, 5 II 2016, [online] http://chojnice24.pl/artykul/22014/ mandat-legowskiego-do-wygaszenia/0/.

Mariusz Janik i informacja publiczna, [online] http://janikmariusz.blogspot.com/.

Ministerstwo Finansów, Obowiązek publikacji, [online] https://www.mf.gov.pl/.

Monitoring Spółek Komunalnych, [online] http://spolki.siecobywatelska.pl/.

Niziołek M., Ochrona przed nadużywaniem prawa do informacji publicznej, „Rzeczpospolita” 
2017, 5 XII, [online] http://www.rp.pl/Urzednicy/312059991-Ochrona-przed-naduzy waniem-prawa-do-informacji-publicznej.html.

O co obywatele pytaja urzędy? Lista wniosków o informacje publiczna w Jedlczu, Rymanowie... oraz skarga na Prezydenta Krosna, 14 XI 2017, [online] http://www.zaleze.com/o-coobywatele-pytaja-urzedy-lista-wnioskow-o-informacje-publiczna-w-jedliczu-rymanowieoraz-skarga-na-prezydenta-krosna/.

Obywatel pyta, urzad odpowiada, 15 V 2015, [online] http://chojnice24.pl/artykul/20448/ obywatel-pyta-urzad-odpowiada/.

Odpowiedź na wniosek, [online] https://pl.scribd.com/document/364434218/odpowied\% C5\%BA-na-wniosek-1-pdf.

Odpowiedź na wniosek z dnia 30 X 2017, [online] https://pl.scribd.com/document/364433 519/Odpowied\%C5\%BA-Na-Wniosek-z-Dnia-30-10-2017-2.

Orange Crush, 13 V 2014, [online] https://edwardsnowden.com/2014/06/13/orange-crush/. Pach M., Trybunat kasuje obywatela, „Rzeczpospolita” 2018, 23 III, [online] http://www.rp.pl/ Opinie/303239984-Trybunal-kasuje-obywatela---Maciej-Pach-o-ignorowaniu-przez-TKwnioskow-o-udostepnienie-informacji-publicznej.html.

Pieńkosz P., Dostęp do informacji publicznej ma być petny, „Dziennik Gazeta Prawna” 2016, 6 VIII, [online] http://prawo.gazetaprawna.pl/artykuly/964937,dostep-do-informacjipublicznej-ma-byc-pelny.html.

Płachciak A., Sena koncepcja rozwoju jako wolności a idea sustainable development, „Annales. Etyka w Życiu Gospodarczym” 2010, Vol. 13, nr 1, [online] http://www.annalesonline.uni. lodz.pl/archiwum/2010/2010_01_plachciak_149_156.pdf.

Podstawy statystyki. Podręcznik, red. W. Starzyńska, Warszawa 2009.

Poradnia Sieci Watchdog, [online] https://porady.siecobywatelska.pl/.

Projekt ustawy o dostępie do informacji publicznej, Sejm RP III kadencji, druk nr 2094, Warszawa, 30 VI 2000, [online] http://orka.sejm.gov.pl/Rejestrd.nsf/wgdruku/2094/\$file/ 2094.pdf.

Przyjazny urząd? Dostęp do informacji publicznej na wniosek w gminach i miastach województwa ślaskiego. Raport z monitoringu, oprac. G. Wójkowski, J. Podgórska-Rykała, Katowice 2012.

Rejestr wniosków o udostępnienie informacji publicznej, Biuletyn Informacji Publicznej Urzędu Miasta Olsztyna, [online] http://bip.olsztyn.eu/bip/dokument/340417/rejestr_ wnioskow_o_udostepnienie_informacji_publicznej_2018r_/.

Rejestr wniosków o udostępnienie informacji publicznej, Słupsk, [online] http://bip.um.slupsk. $\mathrm{pl} /$ udostepnienie_informacji_publicznej/dokumenty/1327.html.

Rejestry prowadzone w Urzędzie Miasta Bydgoszczy, [online] http://bip.um.bydgoszcz.pl/ na_skroty/rejestry-prowadzone-w-umb/.

Rydlewski G., Szustakiewicz P., Golat K., Udzielanie informacji przez administracje publiczna (teoria i praktyka), Warszawa 2012.

Rymanów informacja o ilości wniosków inf. publiczna 2014-2017, [online] https://pl.scribd. com/document/364433879/Rymanow-Informacja-o-Ilo\%C5\%9Bci-Wnioskow-Inf-Pub liczna-2014-2017.

Sen A., Rozwój i wolność, przeł. J. Łoziński, Poznań 2002. 
Should You Pay Be Private?, BBC, The Real Story, 10 II 2018, [online] http://www.bbc.co.uk/ programmes/w3csvqgm.

Sitniewski P., Fundacja JAWNOSC.PL, [online] https://legislacja.rcl.gov.pl/docs//2/12304 351/12465407/12465410/dokument314990.pdf.

Suchodolska M., Informacja publiczna do odbioru w urzędzie, „Dziennik Gazeta Prawna” 2018, $16 \mathrm{~V}$, [online] http://serwisy.gazetaprawna.pl/samorzad/artykuly/1123985,jawnosc-info rmacja-publiczna-w-urzedzie-w-gminie-poswietne.html.

Szulc M., Zalewski Ł., Podatki największych przedsiębiorstw: więcej jawności niż w Polsce tylko w Skandynawii i Australii, „Dziennik Gazeta Prawna” 2017, 4 IV, [online] http://podatki. gazetaprawna.pl/artykuly/1032536,jawne-podatki-najwiekszych-przedsiebiorstw-ustawacit.html.

Szymecka M., Grzywna dla komendanta Policji, 1 II 2018, [online] http://chojnice24.pl/ artykul/26511/grzywna-dla-komendanta-policji/.

Szymon Osowski, [online] https://web.facebook.com/osowski.szymon.

Świętochowska E., Brak dostępu do informacji niejawnych trzeba uzasadnić, „Dziennik Gazeta Prawna” 2017, 20 VII, [online] http://prawo.gazetaprawna.pl/artykuly/1059037,brakdostepu-do-informacji-niejawnych-uzasadnienie.html.

Taczkowska-Olszewska J., Dostęp do informacji publicznej w polskim systemie prawnym, Warszawa 2014, Monografie Prawnicze.

Taradejna R., Taradejna M., Dostęp do informacji publicznej a prawna ochrona informacji dotyczacych dziatalności gospodarczej, spotecznej $i$ zawodowej oraz życia prywatnego, Toruń 2003.

Thompson J.B., Skandal polityczny. Wtadza i jawność w epoce medialnej, przeł. M. Hambura, Warszawa 2010.

Ulicka G., Nowe ruchy spoteczne. Niepokoje i nadzieje wspótczesnych spoteczeństw, Warszawa 1993. Ustawa o jawności życia publicznego, Rządowe Centrum Legislacji, [online] https://legislacja. rcl.gov.pl/projekt/12304351.

Ustawa $z$ dnia 3 października 2008 r. o udostępnianiu informacji o środowisku i jego ochronie, udziale spoteczeństwa $w$ ochronie środowiska oraz o ocenach oddziatywania na środowisko, Dz.U. 2008 nr 199 poz. 1227.

Ustawa $z$ dnia 5 sierpnia 2010 r. o ochronie informacji niejawnych, Dz.U. 2010, nr 182, poz. 1228. Ustawa z dnia 6 września 2001 r. o dostępie do informacji publicznej, Dz.U. 2001, nr 112, poz. 1198.

Wałdoch M., Dociekliwi jako nowy ruch spoteczny: aspekty polityczne prawa dostepu do informacji publicznej $w$ Nowej Zelandii, „Politeja” 2017, nr 3(48), https://doi.org/10.12797/ Politeja.14.2017.48.12.

Wiadomość e-mail z Urzędu Miejskiego w Sopocie do autora, 2 VIII 2016, archiwum autora. Wiadomość e-mail z Urzędu Gminy Słupsk, 27 II 2017, archiwum autora.

Wilk B., Wtadza wcią̇ ukrywa personalia osób, którym ptaci, „Dziennik Gazeta Prawna” 2016, 18 VII, [online] http://prawo.gazetaprawna.pl/artykuly/960701,wladza-wciaz-ukrywapersonalia-osob-ktorym-placi.html.

Wiśniewska A., Ktamstwo w kolorze niebieskim, 31 X 2017, [online] http://chojnice24.pl/ artykul/25887/klamstwo-w-kolorze-niebieskim/. 
Wiśniewska A., Potajanki od dyrektorki i dla dyrektorki, 14 XII 2017, [online] http://chojni ce24.pl/artykul/26215/polajanki-od-dyrektorki-i-dla-dyrektorki/15/.

Wiśniewska A., Watdoch nie pomówit burmistrza, 9 XI 2017, [online] http://chojnice24.pl/ artykul/25951/waldoch-nie-pomowil-burmistrza/.

Wyrok Naczelnego Sądu Administracyjnego w Warszawie, 1 II 2018, sygn. I OSK 699/16.

Wyrok Naczelnego Sądu Administracyjnego w Warszawie, 8 III 2017, sygn. I OSK 1312/15.

Wyrok Wojewódzkiego Sądu Administracyjnego w Gdańsku, 5 IV 2017, sygn. II SA/Gd 7/17.

Wyrok Wojewódzkiego Sądu Administracyjnego w Gorzowie Wielkopolskim, 24 V 2017, sygn. II SAB/Go $1 / 17$.

Wyrok Wojewódzkiego Sądu Administracyjnego w Rzeszowie, 19 V 2017, sygn. II SAB/Rz $11 / 17$.

Wyrok Wojewódzkiego Sądu Administracyjnego w Warszawie, 1 XII 2017, sygn. II SA/Wa $596 / 17$.

Marcin WAŁDOCH - doktor nauk o polityce, adiunkt w Zakładzie Historii Myśli Politycznej i Ruchów Społecznych Instytutu Nauk Politycznych Uniwersytetu Kazimierza Wielkiego w Bydgoszczy. 